https://doi.org/10.52058/2708-7530-2021-3(9)-136-146

Непомнящий Олександр Михайлович доктор наук 3 державного управління, професор, Заслужений будівельник України, Президент Громадської спілки «Міждержавна гільдія інженерів-консультантів», професор кафедри публічного адміністрування, Міжрегіональна Академія управління персоналом, вул. Фрометівська, 2, м. Київ, 03039, тел.: (044) 264-52-54, e-mail: n_a_m@ukr.net, https://orcid.org/ 0000-0002-5766-3150

\title{
ДЕРЖАВНЕ УПРАВЛІННЯ ІНЖИНІРИНГОВОЮ ДІЯЛЬНІСТЮ ЯК ОБ'ЄКТ ДОСЛІДЖЕННЯ ВІТЧИЗНЯНОЇ ДЕРЖАВНО-УПРАВЛІНСЬКОЇ НАУКИ
}

Анотація. На часі, інжиніринг є новаторською темою для комерційноприбуткового бізнесу України, адже виступає інструмент підвищення іiї компетентності, ефективності та ринково-економічної позиції загалом. Державне управління інжиніринговою діяльністю в Україні скеровує та координує розвиток та становлення інжинірингу, досліджуючи основні аспекти його провадження : відповідність закону, залучення прозорих інвестицій та укладення гласних контрактно-договірних угод. В той же час, для державно-управлінської науки важливо дослідити проблемну галузево та комплексно, звернувшись до понять інжинірингової діяльності із одночасним дослідженням іiі ретроспективного, етапного розвитку.

Не менш актуальним $є$ аналіз міжнародних практично-теоретичних основ інжинірингу як передумов формування сучасного державно-управлінського апарату управління на теренах України. Задля цього необхідною є актуалізація стилістики функціонального, видового та системного призначення інжинірингової діяльності у Європі.

Окрім того, зростання ролі та затребуваності інжинірингу в Україні в останнє десятиліття породжує необхідність його розуміння урядом та оперативного реагування на соціально-наукові та економічно-фінансові зміни, що виникають як наслідок. Відтак, завдання державно-управлінської науки $є$ пошук оптимального, економного та науково грамотного рішення, що сприятиме зменшенню термінологічних рамок здійснення проєкту - та, одночасно, підвищить геометричну прогресивність капіталовкладень, зменшивши обсяги інвестиційного фінансування.

До того ж, процес інжинірингової діяльності напряму залежить від стану 
науки. Особливої актуальності набуває кооперація між науковцями-теоретиками, науковцями-практиками та кінцевим елементом системи - державноуправлінським апаратом, що реалізує владно-урядову інжинірингову політику в Україні.

Ключові слова: інжиніринг, інжинірингова діяльність, розвиток, проєкт, послуга, науково-технічний прогрес, комерційна ефективність.

Nepomnyashchy Oleksandr Mykhailovych Doctor of Science in Public Administration, Professor, Honored Builder of Ukraine, Professor of the Department of Public Administration, Interregional Academy of Personnel Management, Frometivska St., 2, Kyiv, 03039, tel . (044) 264-52-54, e-mail: n_a_m@ukr.net, https://orcid.org/0000-0002-5766-3150.

\section{STATE DEPARTMENT OF ENGINEERING ACTIVITY AS AN OBJECT OF RESEARCH OF DOMESTIC PUBLIC ADMINISTRATION SCIENCE}

Abstract. At the moment, engineering is an innovative topic for commercial and profitable business of Ukraine, because it is a tool to increase its competence, efficiency and market and economic position in general. The State Administration of Engineering in Ukraine directs and coordinates the development and formation of engineering, exploring the main aspects of its implementation: compliance with the law, attracting transparent investment and concluding public contractual agreements. At the same time, it is important for public administration science to study the problem in a branch and complex way, turning to the concepts of engineering activities with the simultaneous study of its retrospective, staged development.

No less relevant is the analysis of the international practical and theoretical foundations of engineering as a prerequisite for the formation of a modern public administration in Ukraine. To do this, it is necessary to update the style of functional, specific and systemic purpose of engineering activities in Europe.

In addition, the growing role and demand for engineering in Ukraine over the last decade makes it necessary for the government to understand it and respond promptly to the resulting socio-scientific and economic-financial changes. Therefore, the task of public administration science is to find the optimal, economical and scientifically competent solution that will reduce the terminological framework of the project - and, at the same time, increase the geometric progressiveness of investment by reducing investment funding.

In addition, the process of engineering directly depends on the state of science. The cooperation between scientists-theorists, scientists-practitioners and the final element of the system - the state-administrative apparatus, which implements the government- 
government engineering policy in Ukraine, becomes especially important.

Keywords: engineering, engineering activity, development, project, service, scientific and technical progress, commercial efficiency.

Постановка проблеми. Факти свідчать про те, що стан та рівень сучасного інжинірингу в Україні, порівняно із країнами Свропи, є суттєво нижчим. Так, існує неприхована необхідність покращення масштабно-асортиментної складової функціонування компаній, перепрофілювання акцентів державного управління даної галузі. Державно-управлінська наука в Україні виступає координатором та посередником між владою та організаторами інжинірингових проєктів. Актуальним $\epsilon$ аналіз проблематики розвитку, розуміння та вдосконалення інжинірингової діяльності. Окрім того, потрібним є дослідження комерційної, фінансово-економічної та науково-виробничої складової діяльності компаній. Одночасно, не менш важливо розглянути основи структури інжинірингу, напрямків та перспектив його становлення в Україні - iз «прив'язкою» до українського ринку послуг та державно-управлінських процесів, що диктують стилістику інжиніринг-активності.

Аналіз останніх досліджень і публікацій. Інжинірингова діяльність, в силу власної глобалізаційної експансії, $\epsilon$ предметом ряду науково-теоретичних досліджень. Для розуміння сутності інжинірингу та державно-управлінської політики щодо нього необхідно розуміти його теоретичну, методологічну та практичну складові. Так, застосовним у даному випадку $є$ як міжнароднозарубіжний (Д. Мартін, М. Робсон, М. Гаммер, Д. Гаррінгтон, Д. Чампі), так і національний ( В. Кондратьєв, К. Литвинов, I. Мазур, Ю. Чубатюк, Н. Янковський) наукові доробки. Проте, потрібно відзначити закономірність : поняття ефективного інжинірингу $є$ для України досить новим. Зазначені вітчизняні вчені акцентують увагу на теоретичних підтекстах та генезі інжинірингової діяльності - водночас, наукове обгрунтування даної ніші послуг як інструменту нарощування фінансово-політичного потенціалу країни знаходиться на стадії становлення.

Мета статті - дослідити закономірності та специфіку державного управління інжиніринговою діяльністю, виокремивши іії особливості як об'єкту дослідження державно-управлінської науки в Україні.

Виклад основного матеріалу. Загалом, поняття «інжиніринг» варто розглядати як передумову створення кінцевого продукту. Примітно, що така діяльність $є$ можливою лише за умови залучення розумового потенціалу інтелекту. Через це, говоримо про ще одну характерну рису інжинірингу наявність людського капіталу як рушійної сили новацій.

Крім того, комплексне розуміння інжинірингової діяльності може бути 
сформовано шляхом аналізу Європейської економічної комісії ООН, де він визначений як сукупність проєктно-практичних робіт, метою яких є ефективізація інженерно-технічної галузі виробництва. В той же час, Американська Рада інженерів з професійного розвитку (ECPD) зазначає, що інжиніринг має творчу генезу, котра $є$ передумовою проєктно-розробницької діяльності в області експлуатації стратегічних об’єктів інфраструктури [1].

Потрібно зауважити, що державне регулювання інжинірингової діяльності в Україні відбувається посередництвом нормативно-правового регулювання. Так, поняття інжинірингу найчастіше ототожнюється зі сферою будівництва. Статтею 1 закону України «Про архітектурну діяльність» № 687-XIV від 20.05 .1999 р. інжинірингова діяльність у сфері будівництва визначена як надання інженернотехнічних послуг, що базуються на основні фінансово-технічних досліджень та експертиз, що поєднуються із організаторсько-розробницькою діяльністю в сфері проєктної документації. Крім того, законодавцем інжиніринг ототожнюється із проведенням торгів на конкурсних засадах. По суті, аспект державноуправлінського контролю в Україні виявляється у тому, що інжинірингова діяльність має чітку форму вираження, котра, окрім іншого, включає технічноархітектурне проєктування та економічно-фінансові, раціоналізаторські та винахідницькі консультації (висновок, що прямо виходить із положень статті 1 згаданого Закону) [2].

Разом $з$ тим, державне управління у галузі інжинірингу здійснюється шляхом визначення його понятійно-категоріальних ознак у Національному класифікаторі ДК 009:2010 «Класифікація видів економічної діяльності». Відзначимо, що класифікатор затверджувався двома наказами Держспоживстандарту України № 457 та №530 від 11.10 .2010 р. та 29.11.2010 р. відповідно. Відтак, інжинірингову діяльність у даному випадку віднесено до підвиду професійної та науково-технічної. Класифікатор оперує поняттям інженерного дизайну (визначається як науково-консалтингова діяльність у сфері процесноструктурного проєктування шаблонів, ескізів, системних інструментів тощо). Окрім того, законодавець розширює сферу дії інженерії шляхом віднесення до іiі складу транспортно-будівничих, водно-управлінських, електронно-технічних та технологічно-будівничих проєктів. Таким чином відбувається затвердження контрольно-наглядового концепту з боку влади : для України важливо побудувати вдосконалену структуру інжинірингової регламентації [3].

Поняття інжинірингу, одночасно, фігурує у Податковому кодексі України № 2755-VI від 02.12.2010 р. Цим продемонстровано тісний зв'язок останнього iз фінансово-економічною галуззю державного управління та їхню взаємозалежність. 3 точки зору законодавчої техніки, дефініція $\epsilon$ майже ідентичною наданій у Законі України «Про архітектурну діяльність» № 687-XIV 
від 20.05.1999 р. Отже, відповідно до підпункту 14.1.85 статті 14 Податкового кодексу України, інжинірингова діяльність $є$ виконанням робіт наукововиробничого та проєктно-дослідницького характеру. Додатково відзначається, що інжиніринг є дотичним до техніко-технологічного та консультаційно-авторського процесу розробки новітніх моделей та зразків, що наділені цензом корисного призначення [4].

У дійності, сфера регламентації інжинірингу є досить розгалуженою, через що їі державне регулювання не завжди є послідовним. Так, дослідники О. Кузьмін та Н. Городиська відзначають, що визначення конкретних «рамкових інжинірингових послуг» $є$ неможливим 3 точки зору економічного вчення та варіативності замовницько-економічного підтексту, котрий визначає умови подібних договірних зобов'язань. Ринок інжинірингу є динамічним - це причина виникнення колізійності між нормативно-регулятивним апаратом та способами, за допомогою яких здійснюється державне регулювання інжинірингової діяльності в Україні. Вчені також відзначають, що дефінітивна точність та вичерпний перелік робіт у даній галузі стануть чинником ускладнення, а не полегшення управлінських процесів [5].

Водночас, досить алогічною видається владно-урядова позиція щодо ототожнення понять «інжиніринг» та «інжинірингова діяльність» у законі України «Про архітектурну діяльність» № 687-XIV від 20.05.1999 р. Слушно зазначити, що у такий спосіб звужується перелік призначень та видів робіт, що мають місце під час інженерно-проєктувального процесу. Більше того, відбувається взаємовиключення норм, задекларованих у Національному класифікаторі ДК 009:2010 «Класифікація видів економічної діяльності» ( наказ Держспоживстандарту №530 від 29.11.2010р.), де надано обширний перелік інжинірингово-технологічної зайнятості із детальним виокремленням іiі технологічно-управлінського підтексту.

За загальним правилом, інжиніринг та його державно-управлінське регулювання в Україні має чіткі рамки в силу його галузевості. Однак, нерідко проєктна діяльність пов'язана із промислово-виробничими, маркетинговими або авторськими послугами. У цьому контексті недосконалою є відсутність у законі України «Про авторське право і суміжні права» № 3792-XII від 23.12.1993 р. та особливо - законі України «Про охорону прав на промислові зразки» № 3688-XII від 15.12.1993 р. спеціальної норми-положення, яка б врегулювала правову природу інжинірингової операції, що апріорно пов'язана із правом інтелектуальної власності - адже кінцевим результатом інжинірингу нерідко $\epsilon$ винахід, корисна модель або промисловий зразок.

Доцільно зауважити, що процес державно-управлінського регулювання інжинірингу в Україні шляхом затвердження нормативно-правової бази налічує 
три структурних рівні — розподіл зумовлений юридичною силою відповідних актів.

Так, на макрорівні відбувається регламентація діяльності суб’єктів комерційної діяльності із застосуванням системно-кодифікованих джерел законодавства. Комерція, відтак, $є$ прямо дотичною до інжинірингововинахідницького процесу. Доцільним буде відмітити положення Цивільного кодексу України № 435-IV від 16.01.2003 р. - щодо регламентації процесу надання послуг); Господарського кодексу України № 436-IV від 16.01.2004 p. щодо виокремлення основ прибутково-фінансової діяльності суб'єктів бізеспідприємництва, зокрема - у галузі капітального будівництва; Податкового кодексу України № 2755-VI від 02.12.2010 p. - щодо оподаткування та гіпотетичних податкових пільг, які може отримати суб'єкт господарювання, діяльність якого визнається інжиніринговою за проєктно-організаторською ознакою новаторства [6].

Варто, однак, виділити певні неточності державно-управлінського регулювання даної сфери. Так, Цивільний кодекс України № 435-IV від 16.01.2003 р. штучно обмежує інжинірингову діяльність у сфері будівництва лише за умови наявності нерухомого майна як об’єкта управління. В свою чергу, Господарський кодекс України № 436-IV від 16.01.2004 р. містить специфічнопроцедурне підгрунтя, що виокремлює специфіку інженерно-будівничих послуг - проте його норми не оперують поняттям, сутністю та юридико-правовою природою інжинірингової діяльності. Наостанок, норми Податкового кодексу України № 2755-VI від 02.12.2010 р. не включать можливість надання засобів фінансово-економічної амортизації особам-замовникам або особам-виконавцям інжинірингових послуг. Водночас, Кодексом виокремлено поняття інжинірингу, проте не надано дефінітивного означення інжинірингових послуг, котрі $\epsilon$ предметом регулювання податково-економічного законодавства України. У цьому контексті варто нагадати існування Національного класифікатора ДК 009:2010 «Класифікація видів економічної діяльності» (наказ Держспоживстандарту №530 від 29.11.2010 р.). За його положеннями, поняття інжинірингової діяльності та інжинірингових послуг або мають ідентичне фінансово-правове значення, або кожен з них потребує одиничної термінології (код 71.12, КВЕД 009:2010).

Відповідно, на мезорівні в Україні відбувається більш конкретно-профільне державне регулювання інжинірингу. В першу чергу, здійснення відбувається шляхом прийняття законів України та постанов Кабінету Міністрів України. Доцільно виокремити закон України «Про архітектурну діяльність» № 687-XIV від 20.05.1999 р.; закон України «Про основи містобудування» № 2780-ХІІ від 16.11 .1992 р.; закон України «Про регулювання містобудівної діяльності» № 3038-VI від 17.02.2011 р.; закон України «Про відповідальність за 
правопорушення у сфері містобудівної діяльності» № 208/94-ВР від 14.10.1994 р. тощо.

Тобто, варто констатувати галузевий характер владно-урядового контролю у галузі інжинірингової діяльності, притаманний Україні. Слушним є зауваження В. Кащишина, котрий наголошує на необхідності державного ліцензування як кінцевого суб’єкта комерційної діяльності, так і безпосереднього виконавця послуг. Науковець відзначає, що обсяг, інтенсивність та специфіка інжинірингу зумовлює необхідність контрольно-наглядової державної активності. Окрім того, діяльність інжинірингової компанії є ризиковою для замовника, виконавця та третіх осіб [7].

Власне, цим зумовлюється необхідність конструювання галузевого рівня державно-управлінського регулювання інжинірингу. Так, владно-урядовий апарат України визначає інжиніринг як комплекс проєктно-експлуатаційних стандартів, що потребує дотримання певного рівня. Підкреслюється, що кінцевий об'єктрезультат інжиніринг-діяльності повинен відповідати вимогам та критеріям функціональності, безпечності та ефективності використання. Як наслідок, положення Національного класифікатора ДК 009:2010 «Класифікація видів економічної діяльності» (наказ Держспоживстандарту №530 від 29.11.2010р.) та Державних будівельних норм України № v0046307-93 від 27.04.1993 p. ілюструють державну стандартизацію та нормування даної розробницькоінженерної галузі.

Однак, варто наголосити на недослідженості інжиніринг-ринку України. Так, Л. Траченко зазначає, що держава не здійснює спроб статистичної кодифікації та грунтовного аналізу робітничо-виконавчої складової даної галузі. Несегментований ринок послуг призводить до законодавчо-виконавчих колізій. Зауважимо, що наведення ретроспективно-прогресивних даних використовується країнами Європи як спосіб налагодження позиції інжинірингових послуг у національній фінансово-економічній системі [8].

Іншою проблемою $є$ невідповідність ситуації із інжиніринг-діяльністю та потреб, що ставить перед інжинірингом економічна ситуація в Україні. Так, період 2013-2020 років відзначається низьким рівнем інжиніринг-активності : інновації майже не запроваджуються, нові продукти (послуги) не виходять на ринок - i, як наслідок, не споживаються та не поповнюють бюджетнокошторисну статтю державного доходу. Потенціал інжинірингової компанії визначається не лише їі внутрішньою політикою, але й стилістикою державного регулювання.

Констатуємо, що складність контрольно-наглядової функції держави під час здійснення інжинірингу в Україні пояснюється генезою його виникнення (створення на базі конструкторських, наукових та дослідницьких інститутів або 
реорганізація). Фактично, в Україні інжиніринг (періоду 1991-2020рр.) не визначався як принципово новий, концептуальний державно-виробничий проєкт, що є причиною додаткових труднощів у його регулюванні.

На переконання О. Квактун, основними чинниками стагнації ринку інжинірингу в Україні $\epsilon$ неефективність його державного регулювання та корупційні чинники, що супроводжують експертно-документаційний процес погодження проєктів. Додатково, причина неозначеного статусу розробницькопроєктних робіт пов'язана із недосконалим менеджментом компаній. Дослідниця констатує, що дане питання варто розглядати як симбіоз корпоративних та владно-урядових недосконалостей [9].

Одночасно, законодавство України у галузі інжинірингу містить досить стилістичних прогалин. Так, законами України «Про архітектурну діяльність» № 687-XIV від 20.05.1999 р.; «Про основи містобудування» № 2780-ХII від 16.11.1992 р. не окреслено рамок та правової природи маркетингової політики.

На Рис. 1 виокремлено особливості державного управління інжиніринговою діяльністю в Україні.

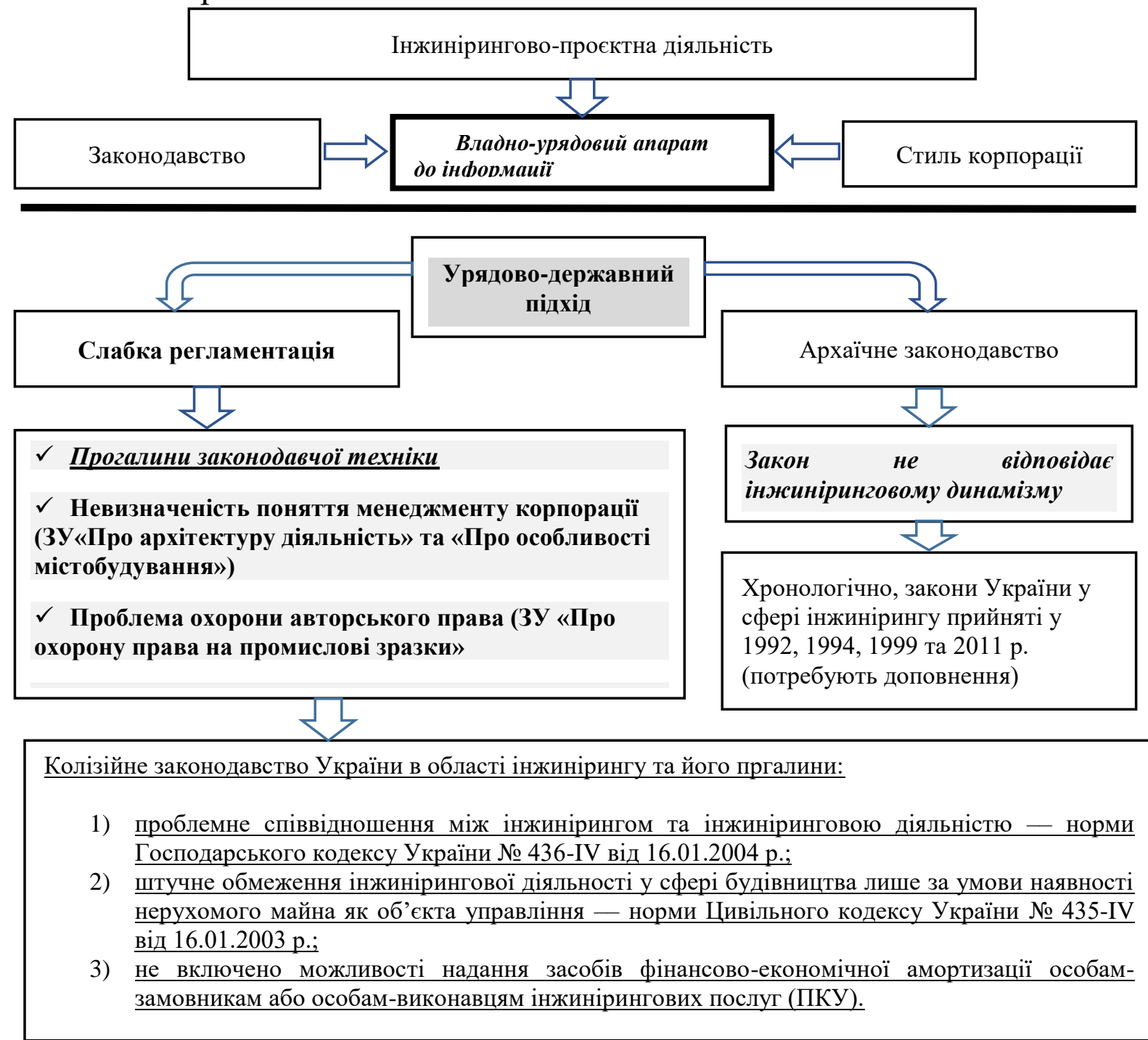

Рис. 1. Державне управління інжинірингом в Україні 
Відзначу, що правова природа інжинірингової діяльності завжди ототожнюється із можливими «заперечними кон'юнтурами». Так, науковець С. Панченко чинниками даної проблеми визначає недостатню об’ємність інноваційного забезпечення; політику влади, що унеможливлює структурноспецифічні зрушення в області економіки; відсутність соціально-урядових стимулів до нарощування підприємницької інженерії (близько 7\% товарів ринку України віднесено до категорії інноваційної продукції за КВЕД 009:2010); несуттєве державно-витратне кошторисне забезпечення суспільно-важливих конструкторсько-розробницьких проєктів [10;11; 12; 13].

Крім того, для України відносна новизна інжинірингу як нової фінансововиробничої ніші створює державно-управлінську невизначеність : Лист комітету Верховної Ради України з питань фінансів і банківської діяльності № 06-10/597 від 15.09.1999 р. ототожнює інжинірингову діяльність із конрактними інженернопроєктними роботами, що виконуються на прохання замовника та пов'язані 3 процесно-підготовчими виробничими етапами (будівничого, промисловоексплуатаційного, інфраструктурно-технологічного винахідництва).

Висновки. Детальний аналіз державного управління інжинірингом в Україні дозволяє зробити висновок про його несистемно-фрагментарну специфіку. Визначення поняття інжинірингової діяльності не має ознак уніфікованості (Цивільний кодекс України, Господарський кодекс України, Податковий кодекс України), а стилістика надання інжинірингової послуги остаточно не визначена профільними нормативними актами - положеннями Національного класифікатора ДК 009:2010 «Класифікація видів економічної діяльності» (наказ Держспоживстандарту №530 від 29.11.2010 р.) та Державних будівельних норм України № v0046307-93 від 27.04.1993 р.

Водночас, неузгоджене нормпроєктування простежується під час співставлення норм Закону України «Про архітектурну діяльність» № 687-XIV від 20.05.1999 р. та Податкового кодексу України № 2755-VI від 02.12.2010 р., де поняття інжинірингу та інжинірингової послуги не розмежовано за ознаками кінцевого фінансово-економічного результату.

Отже, констатуємо наявність тривалого процесу становлення інжинірингової діяльності в Україні. Регулювання останньої, в умовах процесної динаміки та новизни, супроводжується державно-управлінською непослідовністю, що виявляється у недосконалому нормативно-правовому забезпеченні.

\section{Лimepamypa:}

1. Лозовський Л. Ш. Універсальний бізнес-словник / Л. Лозовський, Б. Рейзберг, А. Ратновський, 1997. - 632 с.

2. Закон України «Про архітектурну діяльність» № 687-XIV від 20.05.1999 р. // Відомості Верховної Ради // Режим доступу : https://zakon.rada.gov.ua/laws/show/687-14\#Text 
3. Національний класифікатор ДК 009:2010 «Класифікація видів економічної діяльності» ( наказ Держспоживстандарту №530 від 29.11.2010р.) // Відомості Верховної Ради // Режим доступу : https://zakon.rada.gov.ua/rada/show/vb457609-10\#Text

4. Податковий кодексі України № 2755-VI від 02.12.2010 р. // Відомості Верховної Ради // Режим доступу : https://zakon.rada.gov.ua/laws/show/2755-17

5. Кузьмін О. Типологія інжинірингових підприємств як суб'єктів ринкового середовища та інноваційної інфраструктури / О.С. Кузьмін, Н.А. Городиська, 2012 .- С. 30 -35.

6. Ситник О. Досвід інжинірингової діяльності в сучасному економічному просторі / О.Б. Ситник, 2013. - с. 104 - 116.

7. Кащишин В. Передумови формування потреби підприємств в інжинірингових послугах впровадження нових технології / В.М. Кащишин, 2013 .- с. 56 - 60.

8. Траченко Л. Інжинірингові послуги як об'єкт товарознавства: експертне оцінювання якості / Л. Траченко, монографія, 2014. - 212 с.

9. Квактун О. Сучасний стан світового ринку інжинірингових послуг / О. Квактун, Я. Лисенко, 2013 .- С. $24-32$.

10. Панченко Є. Економічна енциклопедія у трьох томах // ред. С. В. Мочерний, Т.1, 2000. -864 c.

11. Е.А. Романенко Экологическая катастрофа на Донбассе /"Prospects for the Development of Modern Science": Materials of the III International Scientific-Practical Conference. Seoul, Korea: Regional Academy of Management, 2018. - p.84-90.

12. Zhukova I.V. Methodological aspects of public-civic communication research / I.V. Zhukova // Public management - 2019. - № 5 (20) - December 2019. - pp. 75-84.

13. Непомнящий О. М. Аналіз сучасного стану фінансування міжнародними фінансовими організаціями інвестиційних проектів в Україні / О. М. Непомнящий, Ю. Г. Прав // Інвестиції: практика та досвід. - 2016. - № 19. - С. 72-76. - Режим доступу: http://nbuv.gov.ua/UJRN/ipd_2016_19_17

\section{References:}

1. Lozovskyi, L. Reizberh, B., Ratnovskyi, A. (1997). Universalnyi biznes-slovar [Universal business dictionary]. Moscow: INFRA-M [in Russian].

2. Zakon Ukrainy «Pro arkhitekturnu diialnist» : vid 20.05.1999 r. № 687-XIV [Law of Ukraine "On Architectural Activity" from 20.05.1999, № 687-XIV]. (1999). Vidomosti Verkhovnoi Rady - Bulletin of the Verkhovna Rada, 31. Art. 246. Retrieved from https://zakon.rada.gov.ua/laws/show/687-14\#Text [in Ukrainian].

3. Nakaz Derzhspozhyvstandartu Ukrainy "Natsionalnyi klasyfikator DK 009:2010 "Klasyfikatsiia vydiv ekonomichnoi diialnosti” : vid 29.11.2010 r. № 530 [Order of Derzhspozhyvstandart of Ukraine "National Classifier DK 009: 2010" Classification of economic activities" from 29.11.2010, № 530]. zakon.rada.gov.ua. Retrieved from https://zakon.rada.gov.ua/rada/show/vb457609-10\#Text [in Ukrainian].

4. Podatkovyi kodeksi Ukrainy : vid 02.12.2010 r., № 2755-VI [Tax Code of Ukraine from 02.12.2010, № 2755-VI]. (2011). Vidomosti Verkhovnoi Rady - Bulletin of the Verkhovna Rada, 1314, 15-16, 17. Art. 112. Retrieved from https://zakon.rada.gov.ua/laws/show/2755-17 [in Ukrainian].

5. Kuzmin, O.Ye., Horodyska, N.A. (2012). Typolohiia inzhynirynhovykh pidpryiemstv yak subiektiv rynkovoho seredovyshcha ta innovatsiinoi infrastruktury [Typology of engineering enterprises as subjects of market environment and innovation infrastructure]. Tekhnolohichnyi audyt ta rezervy vyrobnytstva - Technological audit and production reserves, 2/2(10), 30-35 [in Ukrainian].

6. Sytnyk, O. (2013). Dosvid inzhynirynhovoi diialnosti v suchasnomu ekonomichnomu prostori [Experience of engineering activity in the modern economic space]. Ekonomika ta upravlinnia pidpryiemstvamy mashynobudivnoi haluzi - Economics and management of machine-building enterprises, 4, 104-116 [in Ukrainian].

7. Kashchyshyn, V. (2013). Peredumovy formuvannia potreby pidpryiemstv v inzhynirynhovykh posluhakh vprovadzhennia novykh tekhnolohii [Prerequisites for the formation of 
enterprise needs in engineering services for the introduction of new technologies]. Tekhnologicheskii audit $i$ rezervy proizvodstva - Technological audit and production reserves, 4(2), 56-60 [in Russian].

8. Trachenko, L. (2014). Inzhynirynhovi posluhy yak obiekt tovaroznavstva: ekspertne otsiniuvannia yakosti [Engineering services as an object of commodity science: expert quality assessment]. Odesa: Atlant [in Ukrainian].

9. Kvaktun, O., Lysenko, Ya. (2013). Suchasnyi stan svitovoho rynku inzhynirynhovykh posluh [The current state of the world market of engineering services]. Ekonomichnyi prostir Economic space, 74, 24-32 [in Ukrainian].

10. Mochernyi, S. V. (Ed.). (2000). Ekonomichna entsyklopediia [Economic Encyclopedia]. (Vols. 1). Kyiv: Vydavnychyi tsentr "Akademiia" [in Ukrainian].

11. Romanenko, E.A. (2018). Ekologicheskaia katastrofa na Donbasse [Environmental disaster in Donbass]. Prospects for the Development of Modern Science: Materials of the III International Scientific-Practical Conference. (pp. 84-90). Seoul, Korea: Regional Academy of Management [in Russian].

12. Zhukova, I.V. (2019). Methodological aspects of public-civic communication research. Public management, 5(20), 75-84 [in English].

13. Nepomniashchyi, O.M., Prav, Yu.H. (2016). Analiz suchasnoho stanu finansuvannia mizhnarodnymy finansovymy orhanizatsiiamy investytsiinykh proektiv $\mathrm{v}$ Ukraini [Analysis of the current state of financing by international financial organizations of investment projects in Ukraine]. Investytsii: praktyka ta dosvid - Investments: practice and experience, 19, 72-76. Retrieved from http://nbuv.gov.ua/UJRN/ipd_2016_19_17 [in Ukrainian]. 